\title{
ФАКТОРЫ ФОРМИРОВАНИЯ ЦЕННОСТЫХ ОРИЕНТАЦИЙ И НРАВСТВЕННЫХ УСТАНОВОК СТУДЕНЧЕСКОЙ МОЛОДЕЖИ
}

В статье представлен анализ понятий «ценности», «нравственные ченности», «антиценности», "псевдоценности». Автор выделяет негативные сочиальные, эконолические, политические факторы, которые влияют на формирование нравственных иенностей студенческой молодежи. Выделены позитивные факторы, способствующие формированию и укреплению нравственньх иенностей студенческой молодежи. Определены негативные факторы, влияюиие на формирование нравственных иенностей студенческой молодежи.

Ключевые слова: ченности, антиценности, нравственные ценности, студенческал молодежь, ценностные ориентации, факторь.

Liudmila Saenko

FACTORS OF FORMATION OF VALUE ORIENTATIONS AND MORAL INSTITUTIONS OF STUDENT YOUTH

The article presents an analysis of the concepts of "values", "moral values", "anti-value", "pseudovalue". The author identifies negative social, economic, political factors that influence the formation of moral values of students. Highlighted positive factors contributing to the formation and strengthening of the moral values of students. Identified negative factors affecting the formation of moral values of students.

Key words: values, anti-values, moral values, students, value orientations, factors.

Bведение / Introduction. В условиях непостоянности и трансформации регионального сообщества проблемы воспитания нравственных качеств личности выходят на первый план абсолютно во всех областях. Существует потребность рассмотрения форм, средств и способов нравственного воспитания с целью установления морально-нравственных ориентиров - ценностных ориентаций студенческой молодежи. Студенческая молодёжь как социальная группа является наиболее интеллигентной, образованной, активной, целенаправленной. И ценностные ориентации современного студенчества определяют в последующем направление формирования сообщества.

Pезультаты и обсужсдение / Results and discussion. В педагогике, психологии, социологии, философии понятия «ценность», «ценностные ориентации» считаются одними из наиболее трудных в плане осмысления и операционализации.

Изучению вопросов, связанных с формированием ценностных ориентаций личности, посвящены работы Л. И. Божович, Н. И. Болдырева, В. В. Зеньковского, И. А. Зимней, И. Г. Лаптева, Н. Г. Марковой, А. 3. Рахимова и др.

В. В. Зеньковский $[1$, с. 86] отмечает: «... нравственные ценности - это способ осмысления, постижения и проектирования нового общества, способ регуляции поведения, основа для выбора действий в трудных жизненных ситуациях».

Категория «ценности» рассматривается в двух направлениях: как компонент когнитивной структуры личности и как элемент мотивационно-потребностной области личности. В педагогике категории «ценности») и «нравственные ценности» рассматриваются через призму поведения и действий личности, через развитие ценностных взаимоотношений личности, анализ его деятельности. 
С. Ф. Масленникова рассматривает понятие «ценности» в следующем ракурсе: «Ценности это своеобразные (позитивные или негативные) общественные установки. Ценности как идеальные или материальные объекты имеют важное значение для личности при удовлетворении его нужд и потребностей〉 $[2$, с. 85$]$.

Д. Б. Мустафина [3] представляет ценности, как «что-то всепроникающее, характеризующее общество в целом, любого человека и любого его действия, любого поступка».

Рассмотрев определения «ценности», можно заключить, что ценность как некий объект имеет важное значение и для отдельной личности, и для общества в целом. Ценности - структурные показатели личности, характеризующее ее направленность, степень регуляции ее поведения в обшестве.

У каждого человека собственная система ценностей, формируемая под воздействием различных факторов. При этом ценности воспринимаются и оцениваются различными людьми по-разному. Для каждой личности свойственна своя, индивидуальная иерархия ценностей.

В основе сознания и поведения личности, его направленности лежат ценностные ориентации. Детерминантами индивидуальной иерархии ценностей являются следующие ценностные ориентации:

- ценности-цели (вечные ценности): непосредственно человеческая жизнь и сам человек. И. Кант определял, что «человек считается абсолютной ценностью, то есть - самоценностью. Все, что находится за пределами человека, лишается каждого смысла». Кроме того, к абсолютным ценностям относится общество;

- духовные ценности: идеи, образцы общественного поведения, культурные ценности; рассмотрение личности в системах «добро и зло», «истина и ложь», «справедливость и несправедливость». В духовных ценностях выражается социальная природа самой личности и обстоятельства ее жизни и деятельности. К духовным ценностям относятся: религия, любовь, воля, свобода, добро, жизнь, семья. Другими словами, духовные ценности - это нравственные ценности, которые считаются специфическим духовным капиталом общества, накапливаемый тысячелетиями;

- материальные (вещественные или инструментальные) ценности или же ценности-средства. Это вещественные ценности, имеющие материальный облик. Например, одежда, предметы обстановки, деньги, орудия труда. Вещественные ценности считаются средством достижения других ценностей. Так, по мнению многих, имея материальные ценности возможно добиться благополучия и признания, имея еду и одежку, возможно сберечь самочувствие, имея неплохую жилплощадь и машину, возможно достичь положения в обществе. В настоящее время вещественные ценности доминируют в системе ценностей молодого поколения.

Наряду с нравственными ценностями существуют псевдоценности и антиценности.

Н. Х. Хакимов [5, с. 162] отмечает, что псевдоценности связаны с духовными парадоксами, свойственными индивидуальному, массовому и социальному сознанию. К ним он приравнивает промахи, заблуждения, предрассудки, иллюзии, легенды, области лжи, не внушающую доверие и неверифицируемую информацию, квазинаучное и религиозное, «чудесные» исцеления, телекинез, телепатию, ясновидение, демоническую одержимость, экзорцизм, астрологию, нумерологию, гадание, оккультизм и т. п.

Антиценности - это не природные, а общественные проявления, связанные с межличностными отношениями, отношениями в обществе. Антиценности - проявления более вещественные, хотя и связанные с духовными отклонениями отдельных личностей и микрогрупп, организаций людей. Все они антигуманны, антисоциальны, представляют собой угрозу для личности, для сообщества, несут опасность деградации. Их источником считается античеловечность, которая в сумме своих отрицательных свойств дает большое многообразие. 
Ю. Ю. Степанюк [4] выделяет следующие группы антиценностей:

- социальные антиценности: войны, угнетение наций, убийство, силовое давление, враждебность, алчность, подозрительность,

- антиценности, возникающие в результате обмана: манипулирование, внушение, дезинформация,

- антиценности в системе (человек - окружающая среда): разрушение среды обитания, подрыв экологической системы, загрязнение окружающей среды,

- антиценности, нацеленные на личность: наркомания, пьянство,

- вредные привязанности, относящиеся к антиценностям: леность, чрезмерное питание, неумение или же нежелание соблюдать простые нравственные нормы (поведение в обществе, собственная гигиена), неорганизованность.

Несмотря на высокое влияние негативных факторов, среди студенческой молодежи закрепляются и положительные факторы, влияющие на формирование нравственных ценностей:

- развитие инновационного личностного капитала студенческой молодежи;

- увеличение уровня профессиональной мобильности, практическая ориентация, самостоятельность, активное принятие новых тенденций среди молодежи;

- молодежная инициативность как средство самореализации и саморазвития, достижения поставленных целей;

- потребность в качественном образовании, овладении профессиональными знаниями и компетенциями;

- поворот к практико-ориентированному образованию;

- заинтересованность и потребность в сохранении своего здоровья, нацеленность на здоровый образ жизни;

- поворот к интернациональному молодежному обществу (научному, профессиональному и т. п.), подъем интеграционных процессов (экономических, политических, гуманитарных).

Заключение/Conclusion. Нравственные ценности прогрессивной студенческой молодежи есть взаимосвязанная система ценностей, которая оказывает интеграционное воздействие друг на друга.

Нравственные ценностей студенческой молодежи зависят от воздействия отрицательных социальных, финансовых, политических факторов:

- трансформация духовно-нравственных ценностей, устоев морали, снятие каких-либо ограничений для достижения собственных целей, собственного успеха;

- размывание норм социальной и личностной ответственности, потеря самоконтроля;

- трансформация семейных отношений, утрата семейных традиций, устоев, размывание семейных ролей и обязанностей;

- снижение показателей физического и психического здоровья молодежи;

- повышение уровня преступности в обществе;

- безработица среди молодежи, снижение мотивации к работе по специальности у выпускников вузов, колледжей;

- низкая заинтересованность молодежи процессами управления на региональном, муниципальном и других уровнях.

Опрос среди студентов вузов г. Ставрополя (426 студентов очной формы обучения различных направлений подготовки) показал, что для студенческой молодежи характерны следующие ценности: самостоятельность и независимость (66\%), интересная работа $(37 \%)$, наличие качественного образования (52\%), успех (40\%), семья (22\%), уважение (18 \%) (можно было выбрать несколько вариантов ответов). 
Все вышесказанное нацеливает на вывод, что сформированная система ценностей молодого человека оказывает непосредственное воздействие на его практическую деятельность. Система ценностных ориентаций определяет направление личности, является базисом выстраивания взаимоотношений между людьми и обществом в целом. Но только сформированные у молодежи нравственные ценности способны положительно влиять на развитие общества.

\section{ЛИТЕРАТУРА И ИНТЕРНЕТ-РЕСУРСЫ}

1. Зеньковский В. В. Педагогика. Клин: Фонд «Христианская жизнь», 2002. 220 с.

2. Масленникова С. Ф. Воспитание нравственных качеств учащейся молодежи как педагогическая проблема // Цивилизационные перемены в России: сборник научных статей по материалам научно-практической конференции. Екатеринбург: Уральский государственный лесотехнический университет, 2013. С. 84-87.

3. Мустафина Д. Б. Проблемы нравственно-этического воспитания в современном мире // Перспективы развития науки и образования: сб. научных трудов по материалам Международной научно-практической конференции: в 13 частях. Люберцы, 2015. С. 106-108.

4. Степанюк Ю. Ю. Нравственное воспитание как залог формирования гражданственности молодежи // Высшая школа. 2016. № 8. С. 88-90.

5. Хакимов Н. Х. Образование как важный фактор в нравственном воспитании учащейся молодежи // Проблемы и достижения современной науки. 2016. № 1 (3). С. 162-164.

\section{REFERENCES AND INTERNET RESOURCES}

1. Zen'kovskij V. V. Pedagogika (Pedagogy). Klin: Fond «Hristianskaja zhizn'». 2002. $220 \mathrm{~s}$.

2. Maslennikova S. F. Vospitanie nravstvennyh kachestv uchashhejsja molodezhi kak pedagogicheskaja problema (Education of moral qualities of students as a pedagogical problem): Civilizacionnye peremeny $\mathrm{v}$ Rossii: sbornik nauchnyh statej po materialam nauchno-prakticheskoj konferencii. Ekaterinburg: Ural'skij gosudarstvennyj lesotehnicheskij universitet, 2013. S. 84-87.

3. Mustafina D. B. Problemy nravstvenno-jeticheskogo vospitanija v sovremennom mire (Problems of moral and ethical education in the modern world) // Perspektivy razvitija nauki i obrazovanija: sb. nauchnyh trudov po materialam Mezhdunarodnoj nauchno-prakticheskoj konferencii: v 13 chastyah. Ljubercy, 2015. S. $106-108$.

4. Stepanjuk Ju. Ju. Nravstvennoe vospitanie kak zalog formirovanija grazhdanstvennosti molodezhi (Moral education as the key to the formation of civic youth) // Vysshaja shkola. 2016. № 8. S. 88-90.

5. Hakimov N. H. Obrazovanie kak vazhnyj faktor $v$ nravstvennom vospitanii uchashhejsja molodezhi (Education as an important factor in the moral education of students) // Problemy i dostizhenija sovremennoj nauki. 2016. № 1 (3). S. 162-164.

\section{СВЕДЕНИЯ ОБ АВТОРЕ}

Саенко Людмила Александровна, доктор социологических наук, кандидат педагогических наук, доцент, профессор кафедры социально-гуманитарных дисциплин, АНО ВО «Северо-Кавказский социальный институт», г. Ставрополь. E-mail: la-sanko@yandex.ru

\section{INFORMATION ABOUT AUTHOR}

Liudmila Saenko, Doctor of Social Sciences, Candidate of Pedagogical Sciences, associate Professor, Professor of the Department of social and humanitarian disciplines, North Caucasus social Institute, Stavropol. E-mail: la-sanko@yandex.ru 